\title{
Laboratory Report On The Reduction And Stabilization (Immobilization) Of Pertechnetate To Technetium Dioxide Using Tin(II)apatite
}

\section{J. B. Duncan}

Washington River Protection Solutions LLC

K. Hagerty

AREVA Federal Services

W. P. Moore

R. N. Rhodes

J. M. Johnson

RJ Lee Group

R. C. Moore

Sandia National Laboratories

Date Published

June 2012

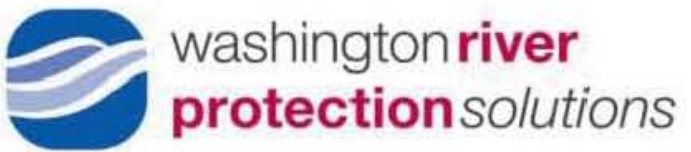

Prepared for the U.S. Department of Energy

Office of River Protection

Contract No. DE-AC27-08RV14800 


\section{LAB-RPT-12-00001 Rev. 0}

\section{EXECUTIVE SUMMARY}

This effort is part of the technetium management initiative and provides data for the handling and disposition of technetium. To that end, the objective of this effort was to challenge tin(II)apatite (Sn(II)apatite) against double-shell tank 241-AN-105 simulant spiked with pertechnetate $\left(\mathrm{TcO}_{4}{ }^{-}\right)$. The $\mathrm{Sn}$ (II)apatite used in this effort was synthesized on site using a recipe developed at and provided by Sandia National Laboratories; the synthesis provides a high quality product while requiring minimal laboratory effort.

The $\mathrm{Sn}$ (II)apatite reduces pertechnetate from the mobile +7 oxidation state to the non-mobile +4 oxidation state. It also sequesters the technetium and does not allow for re-oxidization to the mobile +7 state under acidic or oxygenated conditions within the tested period of time ( 6 weeks). Previous work (RPP-RPT-39195, Assessment of Technetium Leachability in Cement-Stabilized Basin 43 Groundwater Brine) indicated that the Sn(II)apatite can achieve an ANSI leachability index in Cast Stone of 12.8 .

The technetium distribution coefficient for $\mathrm{Sn}(\mathrm{II})$ apatite exhibits a direct correlation with the $\mathrm{pH}$ of the contaminated media. Table A shows Sn(II)apatite distribution coefficients as a function of $\mathrm{pH}$. The asterisked numbers indicate that the lower detection limit of the analytical instrument was used to calculate the distribution coefficient as the concentration of technetium left in solution was less than the detection limit.

Table A. Sn(II)apatite Technetium Distribution Coefficients as a Function of pH.

\begin{tabular}{|c|c|c|}
\hline $\mathbf{p H}$ & $\begin{array}{c}\text { Initial Concentration of } \\
\mathbf{T c}-\mathbf{9 9}(\mathbf{m g} / \mathbf{L})\end{array}$ & $\begin{array}{c}\text { Distribution Coefficient } \\
\left(\mathbf{K}_{\mathbf{d}}\right)\end{array}$ \\
\hline 0.1 & 15.2 & 18 \\
\hline 1 & 17.1 & 237 \\
\hline 1.3 & 17.1 & 6,059 \\
\hline 2.5 & 17.1 & 170,900 \\
\hline 8.5 & 17.1 & $170,900^{*}$ \\
\hline 10.2 & 17.1 & $170,900^{*}$ \\
\hline 11.4 & 17.1 & 65,669 \\
\hline 12.5 & 17.1 & 703 \\
\hline 13.3 & 17.1 & 68 \\
\hline 14 & 17.1 & 36 \\
\hline \multicolumn{2}{|c|}{} \\
\hline "The lower detection limit of the instrument $(10 \mathrm{ppb})$ was used to calculate the $\mathrm{K}_{\mathbf{d}}$ \\
\hline \multicolumn{2}{|l|}{}
\end{tabular}

The loaded sample (200 mg of $\mathrm{Sn}$ (II)apatite loaded with $0.311 \mathrm{mg}$ of Tc-99) was subjected to different molarities of nitric acid to determine if the $\mathrm{Sn}$ (II)apatite would release the sequestered technetium. The acid was allowed to contact for 1 minute with gentle shaking (" $1^{\text {st }}$ wash"); the aqueous solution was then filtered, and the filtrate was analyzed for Tc-99. Table B shows the results of the nitric acid exposure. Another portion of acid was added, shaken for a minute, and filtered ("2 ${ }^{\text {nd }}$ wash"). 
LAB-RPT-12-00001 Rev. 0

Table B. Nitric Acid Leach Test.

\begin{tabular}{|c|c|c|}
\hline \multirow{2}{*}{ Nitric Acid Solution } & \multicolumn{2}{|c|}{ Tc-99 Leached into Filtrate (wt\%) } \\
\cline { 2 - 3 } & $\mathbf{1}^{\mathbf{s t}} \mathbf{W a s h}$ & $\mathbf{2}^{\mathbf{\text { nd }}} \mathbf{\text { ash }}$ \\
\hline $0.01 \mathrm{M}$ & Non Detect & Non Detect \\
\hline $0.05 \mathrm{M}$ & 0.52 & 0.33 \\
\hline $0.1 \mathrm{M}$ & 0.24 & 0.19 \\
\hline $1.0 \mathrm{M}$ & 0.31 & 50.0 (after 72-hour soak) \\
\hline
\end{tabular}

The technetium-loaded Sn(II)apatite was also subjected to water leach tests. The loaded sample (0.2 $\mathrm{g}$ of $\mathrm{Sn}$ (II)apatite was loaded with $0.342 \mathrm{mg}$ of Tc-99) was placed in a $200-\mathrm{mL}$ distilled water column and sparged with air. Samples were taken weekly over a 6-week period, and the dissolved oxygen ranged from 8.4 to $8.7 \mathrm{mg} / \mathrm{L}$ (average $8.5 \mathrm{mg} / \mathrm{L}$ ); all samples recorded less than the detection limit of $0.01 \mathrm{mg} / \mathrm{L} \mathrm{Tc}-99$.

The mechanism by which $\mathrm{TcO}_{2}$ is sequestered and hence protected from re-oxidation appears to be an exchange with phosphate in the apatite lattice, as the phosphorus that appeared in solution after reaction with technetium was essentially the same moles of technetium that were taken up by the $\mathrm{Sn}(\mathrm{II})$ apatite (Table 6 ).

Overall, the reduction of the mobile pertechnetate $(+7)$ to the less mobile technetium dioxide $(+4)$ by $\mathrm{Sn}(\mathrm{II})$ apatite and subsequent sequestration of the technetium in the material indicates that $\mathrm{Sn}$ (II)apatite is an excellent candidate for long-term immobilization of technetium.

The indications are that the $\mathrm{Sn}(\mathrm{II})$ apatite will lend itself to sequestering and inhibiting the reoxidation to the mobile pertechnetate species, thus keeping the radionuclide out of the environment. The Sn(II)apatite would be efficacious in the following scenarios, for example:

- water elution from pertechnetate resins such as SuperLig ${ }^{\circledR 1} 639$

- treatment of pertechnetate containing waste streams from the Effluent Treatment Facility

- treatment of the off gas from the Waste Treatment Plant to capture technetium

- within a groundwater barrier to prevent pertechnetate mobility.

\footnotetext{
${ }^{1}$ SuperLig is a registered trademark of IBC Advanced Technologies, Inc., American Fork, Utah.
} 


\section{Table of Contents}

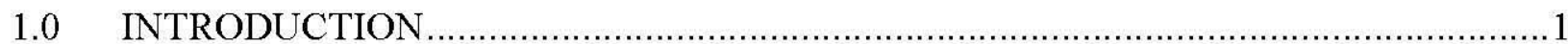

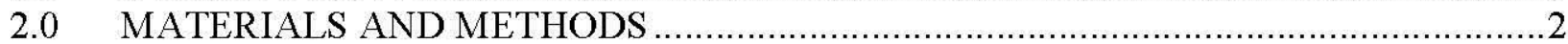

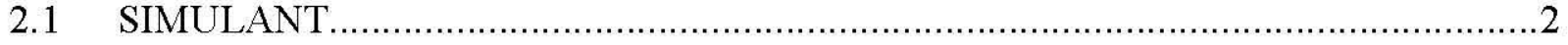

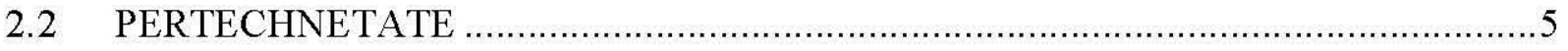

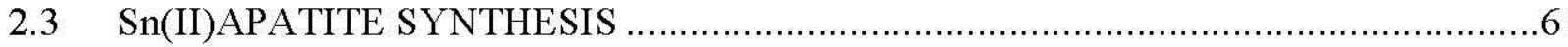

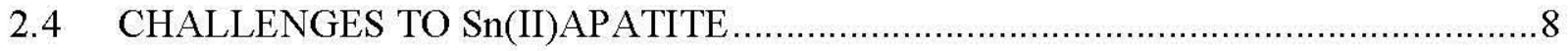

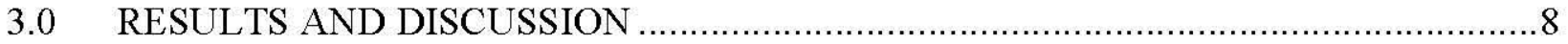

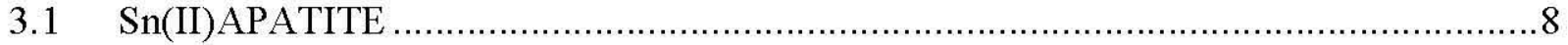

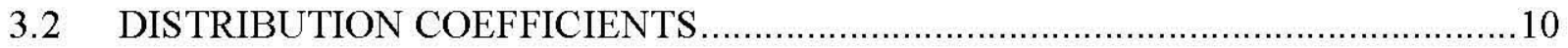

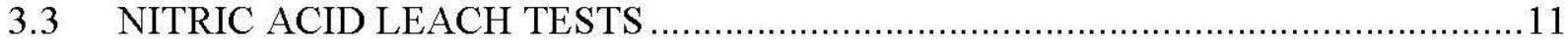

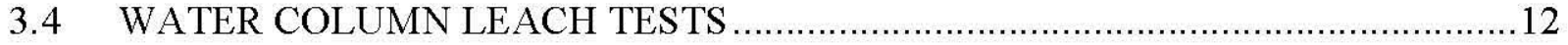

3.5 PROPOSED SEQUESTRATION MECHANISM .............................................13

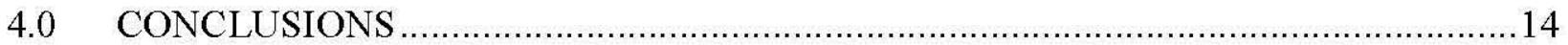

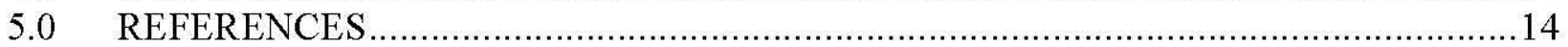

APPENDIX A. Technetium Distribution Coefficient Data ................................................ A-i

\section{List of Tables}

Table 1. Tank 241-AN-105 Double-Shell Tank Simulant Chemical Makeup (1 L Batch)..........3

Table 2. Preparation of AN-105 Simulant without Organies for 2 Liters.............................. 4

Table 3. Distribution Coefficients as a Function of Sodium Molarity and $\mathrm{pH}$........................11

Table 4. Weight Percent Technetium Lost in Nitric Acid Washes..........................................12

Table 5. Water Leach Test....................................................................................... 12

Table 6. Analyses of Deionized Water Medium..................................................................13

\section{List of Figures}

Figure 1. Calibration Curve using Ludlum Model 2929...............................................

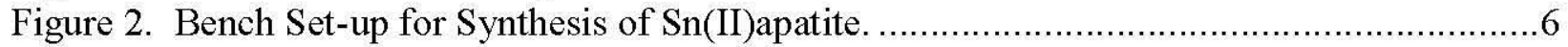

Figure 3. Sn(II)apatite on a Scanning Electron Microscope Mount. ...................................... 8

Figure 4. Secondary Electron Image with EDS of Sn(II)apatite. ...........................................

Figure 5. X-ray Diffraction Pattern of the Sn(II)apatite Formulation.................................. 10 


\section{List of Terms}

\section{Abbreviations}

$\begin{array}{ll}\text { AN-105 } & \text { tank 241-AN-105 } \\ \text { DI } & \text { de-ionized } \\ \text { EDS } & \text { energy dispersive spectrometry } \\ \text { ICP/MS } & \text { inductively coupled plasma/mass spectrometer } \\ \mathrm{K}_{\mathrm{d}} & \text { distribution coefficient } \\ \text { PVDF } & \text { polyvinylidene difluoride } \\ \text { Ru-99 } & \text { ruthenium } 99 \\ \text { SEM } & \text { scanning electron microscope } \\ \text { Tc-99 } & \text { technetium } \\ \text { XRD } & \text { X-ray diffraction }\end{array}$

\section{Units}

$\begin{array}{ll}\mathrm{BV} & \text { bed volume } \\ \mathrm{Bq} & \text { Becquerel } \\ { }^{\circ} \mathrm{C} & \text { degrees Celcius } \\ \mathrm{CPM} & \text { counts per minute } \\ \mathrm{d} & \text { day } \\ \mathrm{g} & \text { gram } \\ \mathrm{kg} & \text { kilogram } \\ \mathrm{L} & \text { liter } \\ \mathrm{MeV} & \text { mega electron volt } \\ \mathrm{M} & \text { moles/liter (mol/L) } \\ \mu \mathrm{L} & \text { microliter } \\ \mu \mathrm{m} & \text { micrometer } \\ \mathrm{mg} & \text { milligram } \\ \mathrm{mL} & \text { milliliter } \\ \mathrm{mmol} & \text { millimole } \\ \mathrm{mrem} & \text { millirem } \\ \mu \mathrm{Sv} & \text { microSeiverts } \\ \mathrm{ppb} & \text { parts per billion } \\ \mathrm{wt} \% & \text { weight percent }\end{array}$




\section{LAB-RPT-12-00001 Rev. 0}

\subsection{INTRODUCTION}

This report documents the laboratory testing and analyses as directed under the test plan, LAB-PLN-11-00010, Evaluation of Technetium Ion Exchange Material against Hanford Double Shell Tank Supernate Simulant with Pertechnetate.

Technetium (Tc-99) is a major fission product from nuclear reactors, and because it has few applications outside of scientific research, most of the technetium will ultimately be disposed of as nuclear waste. The radioactive decay of Tc-99 to ruthenium $99(\mathrm{Ru}-99)$ produces a low energy $\beta^{-}$particle $(0.1 \mathrm{MeV} \max )$. However, due to its fairly long half-life $\left(\mathrm{t}_{1 / 2}=2.13 \mathrm{E} 05\right.$ years), Tc-99 is a major source of radiation in low-activity waste (UCRL-JRNL-212334, Current Status of the Thermodynamic Data for Technetium and its Compounds and Aqueous Species).

Technetium forms the soluble oxy anion pertechnetate $\left(\mathrm{TcO}_{4}{ }^{-}\right)$under aerobic conditions. This anion, which is very mobile in groundwater, poses a health risk (Radiological and Chemical Fact Sheets to Support Health Risk Analyses for Contaminated Areas, Argonne National Laboratory). Several reports have been published on the mobility of the pertechnetate ion in the environment. For example, Tc-99 has been shown to increase in the western Irish Sea as a direct result of the increases in discharge of Tc-99 from the Sellafield reprocessing site. During the period of 1996 to 1998 , the mean committed effective doses to Irish typical and heavy seafood consumers due to Tc-99 were $0.061 \mu \mathrm{Sv}(0.0061 \mathrm{mrem})$ to $0.24 \mu \mathrm{Sv}(0.024 \mathrm{mrem})$ respectively. Technetium-99 emanates from the Enhanced Actinide Removal Plant at Sellafield which removes actinides but is ineffective at removing Tc-99 "Technetium-99 in the Irish marine environment," Smith, et al. 2001). In a study by the International Atomic Energy Agency, it was reported that very mobile radionuclides such as technetium have a soil to plant transfer factor of 100 or greater. The soil to plant transfer factor (dimensionless) is defined as the ratio of the activity concentration of the radionuclide in the plant $(\mathrm{Bq} / \mathrm{kg})$ to that in the soil $(\mathrm{Bq} / \mathrm{kg})$. Furthermore, it was reported that technetium is very mobile in the soil and may be subject to considerable migration to deeper soil layers, (IAEA, Handbook of Parameter Values for the Prediction of Radionuclide Transfer in Terrestrial and Freshwater Environments).

Researchers have identified that redox conditions play an important part in the retardation of mobility of the pertechnetate species ("Assessing field-scale migration of radionuclides at the Nevada Test Site: 'mobile' species," Hu, et al. 2008; "Evidence of ${ }^{99} \mathrm{Tc}$ in Ural River sediments," Aarkrog, et al. 1997). Capitalizing upon the redox conditions and using $\mathrm{Sn}$ (II)apatite, further work has demonstrated that pertechnetate is reduced to the non-mobile $\mathrm{TcO}_{2}$ species. It was also demonstrated that technetium-loaded $\mathrm{Sn}$ (II)apatite achieves a leachability index in Cast Stone of 12.8 (ANSI/ANS-16.1-2003, Measurement of the Leachability of Solidified Low-Level Radioactive Wastes by a Short-term Test Procedure) as reported in RPP-RPT-39195, Assessment of Technetium Leachability in Cement-Stabilized Basin 43 Groundwater Brine. The mechanism appears to be an exchange with the phosphate group in the apatite molecule. It has been reported that the apatite lattice is very tolerant to substitutions (Apatite Structures, Elliott, et al., 2002; "The properties and structure of $\mathrm{Ca}_{10}\left(\mathrm{PO}_{4}\right)_{6}(\mathrm{OH})_{2}$; its relation to tin(II)apatite," McConnell and Foreman, 1966). 


\section{LAB-RPT-12-00001 Rev. 0}

This study is part of the technetium management initiative to provide data for the safe handling and disposition of technetium in Hanford tank waste treatment. To that end, the objective of this study was to challenge $\mathrm{Sn}(\mathrm{II})$ apatite against double-shell tank 241-AN-105 (AN-105) simulant spiked with pertechnetate $\left(\mathrm{TcO}_{4}{ }^{-}\right)$.

\subsection{MATERIALS AND METHODS}

\subsection{SIMULANT}

Envelope A (also known as Double-Shell Slurry Feed and Double-Shell Slurry) was chosen because it is an alkaline $\left(\left[\mathrm{OH}^{-}\right]>1 \mathrm{M}\right)$, high sodium $(>8 \mathrm{M})$ supernate. The AN-105 supernate recipe reported in WSRC-TR-2000-00338, Hanford Waste Simulants Created to Support the Research and Development on the River Protection Project - Waste Treatment Plant, was formulated and spiked with $15 \mathrm{mg} / \mathrm{L}$ of Tc-99. Table 1 shows the simulant recipe.

The simulant was formulated following the directions of Dr. Dan Herting, Process Chemistry, Washington River Protection Solutions LLC. First, all of the acid nitrate salts were mixed in a small portion of de-ionized (DI) water and set aside for later addition. Next, the aluminum source was dissolved; sodium aluminate was used as it dissolves quickly in 60 to $70{ }^{\circ} \mathrm{C} \mathrm{NaOH}$. After the sodium aluminate had dissolved, the temperature was maintained at 40 to $60{ }^{\circ} \mathrm{C}$, and the remaining salts were added beginning with those which dissolve more slowly. Sodium nitrate and sodium nitrite were added last. The order of addition is presented in Table 2 . If the simulant were to be formulated with the organic component, then acidic organics such as oxalic acid would be added with the acid salts, while sodium oxalate would be added with sodium nitrate. The simulant presented a very small amount of solids after 24 hours and was filtered using a $0.45 \mu \mathrm{m}$ PVDF filter. 
LAB-RPT-12-00001 Rev. 0

Table 1. Tank 241-AN-105 Double-Shell Tank Simulant Chemical Makeup (1 L Batch).

\begin{tabular}{|c|c|c|}
\hline Reagent & Formula & $\mathrm{g} / \mathrm{L}$ \\
\hline Boric Acid & $\mathrm{H}_{3} \mathrm{BO}_{3}$ & 0.292 \\
\hline Cadmium Nitrate & $\mathrm{Cd}\left(\mathrm{NO}_{3}\right)_{2} \bullet 4 \mathrm{H} 2 \mathrm{O}$ & 0.009 \\
\hline Calcium Nitrate & $\mathrm{Ca}\left(\mathrm{NO}_{3}\right)_{2} \bullet 4 \mathrm{H} 2 \mathrm{O}$ & 0.236 \\
\hline Cesium Nitrate & $\mathrm{CsNO}_{3}$ & 0.024 \\
\hline Lead Nitrate & $\mathrm{Pb}\left(\mathrm{NO}_{3}\right)_{2}$ & 0.085 \\
\hline Magnesium Nitrate & $\mathrm{Mg}\left(\mathrm{NO}_{3}\right)_{2} \bullet 6 \mathrm{H}_{2} \mathrm{O}$ & 0.057 \\
\hline Potassium Nitrate & $\mathrm{KNO}_{3}$ & 19.221 \\
\hline Silver Nitrate & $\mathrm{AgNO}_{3}$ & 0.026 \\
\hline Zinc Nitrate & $\mathrm{Zn}\left(\mathrm{NO}_{3}\right)_{2} \bullet 6 \mathrm{H}_{2} \mathrm{O}$ & 0.046 \\
\hline Glycolic Acid & $\mathrm{HOCH}_{2} \mathrm{CHOOH}, 70 \mathrm{WT} \%$ & 1.665 \\
\hline Sodium Chloride & $\mathrm{NaCl}$ & 14.984 \\
\hline Sodium Fluoride & $\mathrm{NaF}$ & 0.420 \\
\hline Sodium Chromate & $\mathrm{Na}_{2} \mathrm{CrO}_{4}$ & 4.205 \\
\hline Sodium Sulfate & $\mathrm{Na}_{2} \mathrm{SO}_{4}$ & 1.140 \\
\hline Potassium Molybdate & $\mathrm{K}_{2} \mathrm{MoO}_{4}$ & 0.204 \\
\hline Ammonium Acetate & $\mathrm{CH}_{2} \mathrm{COONH}_{4}$ & 0.513 \\
\hline Aluminum Trihydroxide & $\mathrm{Al}(\mathrm{OH})_{3}$ & 114.77 \\
\hline Sodium Hydroxide & $\mathrm{NaOH}$ & 196.68 \\
\hline Selenium Dioxide & $\mathrm{SeO}_{2}$ & 0.001 \\
\hline Sodium Metasilicate & $\mathrm{Na}_{2} \mathrm{SiO}_{3} \bullet 9 \mathrm{H}_{2} \mathrm{O}$ & 2.135 \\
\hline Sodium Acetate & $\mathrm{NaCH}_{3} \mathrm{COO} \cdot 3 \mathrm{H}_{2} \mathrm{O}$ & 3.865 \\
\hline Sodium Formate & HCOONa & 4.351 \\
\hline Sodium Oxalate & $\mathrm{Na}_{2} \mathrm{C}_{2} \mathrm{O}_{4}$ & 0.929 \\
\hline Sodium Phosphate & $\mathrm{Na}_{3} \mathrm{PO}_{4} \bullet 12 \mathrm{H}_{2} \mathrm{O}$ & 2.281 \\
\hline Sodium Carbonate & $\mathrm{Na}_{2} \mathrm{CO}_{3}$ & 22.149 \\
\hline Sodium Nitrate & $\mathrm{NaNO}_{3}$ & 209.70 \\
\hline Sodium Nitrite & $\mathrm{NaNO}_{2}$ & 166.48 \\
\hline Water & $\mathrm{H}_{2} \mathrm{O}$ & 669.37 \\
\hline
\end{tabular}


Table 2. Preparation of AN-105 Simulant without Organics for 2 Liters.

\begin{tabular}{|c|c|c|}
\hline \multicolumn{3}{|c|}{ STEP 1} \\
\hline In a $2000 \mathrm{~mL}$ Volumetric Flask add & Formula & $\mathrm{g} / 2 \mathrm{~L}$ \\
\hline Water & & 400 \\
\hline \multicolumn{3}{|l|}{ Then add the following compounds: } \\
\hline Boric Acid & $\mathrm{H}_{3} \mathrm{BO}_{3}$ & 0.584 \\
\hline Cadmium Nitrate & $\mathrm{Cd}\left(\mathrm{NO}_{3}\right)_{2} \cdot 4 \mathrm{H}_{2} \mathrm{O}$ & 0.018 \\
\hline Calcium Nitrate & $\mathrm{Ca}\left(\mathrm{NO}_{3}\right)_{2} \cdot 4 \mathrm{H}_{2} \mathrm{O}$ & 0.472 \\
\hline Lead Nitrate & $\mathrm{Pb}\left(\mathrm{NO}_{3}\right)_{2}$ & 0.17 \\
\hline Magnesium Nitrate & $\mathrm{Mg}\left(\mathrm{NO}_{3}\right)_{2} \cdot 6 \mathrm{H}_{2} \mathrm{O}$ & 0.114 \\
\hline Potassium Nitrate & $\mathrm{KNO}_{3}$ & 38.442 \\
\hline Silver Nitrate & $\mathrm{AgNO}_{3}$ & 0.052 \\
\hline Zinc Nitrate & $\mathrm{Zn}\left(\mathrm{NO}_{3}\right)_{2} \cdot 6 \mathrm{H}_{2} \mathrm{O}$ & 0.092 \\
\hline Sodium Chloride & $\mathrm{NaCl}$ & 29.968 \\
\hline Sodium Fluoride & $\mathrm{NaF}$ & 0.84 \\
\hline Sodium Chromate & $\mathrm{Na}_{2} \mathrm{CrO}_{4}$ & 8.41 \\
\hline Sodium Sulfate & $\mathrm{Na}_{2} \mathrm{SO}_{4}$ & 2.28 \\
\hline Potassium Molybdate & $\mathrm{K}_{2} \mathrm{MoO}_{4}$ & 0.408 \\
\hline \multicolumn{3}{|l|}{ Mix thoroughly. } \\
\hline \multicolumn{3}{|c|}{ STEP 2} \\
\hline \multicolumn{3}{|c|}{ Mix the following in a separate container: } \\
\hline Sodium Aluminate & $\mathrm{Na}_{2} \mathrm{OAl}_{2} \mathrm{O}_{3} \cdot 3 \mathrm{H}_{2} \mathrm{O}$ & 320.77 \\
\hline Sodium Hydroxide & $\mathrm{NaOH}$ & 275.66 \\
\hline Selenium Dioxide & $\mathrm{SeO}_{2}$ & 0.002 \\
\hline Sodium Meta Silicate & $\mathrm{Na}_{2} \mathrm{SiO}_{3} .5 \mathrm{H}_{2} \mathrm{O}$ & 3.188 \\
\hline Sodium Phosphate & $\mathrm{Na}_{3} \mathrm{PO}_{4} \cdot 12 \mathrm{H}_{2} \mathrm{O}$ & 4.562 \\
\hline Water & & 600 \\
\hline \multicolumn{3}{|c|}{ Mix thoroughly, then add this solution to the volumetric flask. } \\
\hline \multicolumn{3}{|c|}{ STEP 3} \\
\hline Add to the volumetric flask: & Formula & \\
\hline Sodium Carbonate & $\mathrm{Na}_{2} \mathrm{CO}_{3}$ & 44.298 \\
\hline \multicolumn{3}{|l|}{ Mix thoroughly. } \\
\hline \multicolumn{3}{|l|}{ Add: } \\
\hline Sodium Nitrate & $\mathrm{NaNO}_{3}$ & 419.4 \\
\hline Sodium Nitrite & $\mathrm{NaNO}_{2}$ & 332.96 \\
\hline \multicolumn{3}{|l|}{ Technetium } \\
\hline \multicolumn{3}{|l|}{ Mix thoroughly. } \\
\hline Add water to the $2000 \mathrm{ml}$ mark. & & \\
\hline
\end{tabular}




\section{LAB-RPT-12-00001 Rev. 0}

\subsection{PERTECHNETATE}

Pertechnetate was obtained as ammonium pertechnetate from the Oak Ridge High Flux Isotope Reactor. The material was solubilized in DI water, and appropriate dilutions were carried out and confirmed using a PerkinElmer ${ }^{\circledR 2}$ Elan DRC-e model inductively coupled plasma/mass spectrometer (ICP/MS).

For testing the concentration of pertechnetate remaining in the liquid after reduction by the $\mathrm{Sn}$ (II)apatite, a standard curve was generated using a Ludlum Model 2929 dual scaler, Figure 1. The standard curve was generated by comparing the 5-minute averaged and backgroundcorrected counts to the analyses obtained using the ICP.

For the resin test, a sample of $200 \mu \mathrm{L}$ of resin bed effluent at progressive bed volumes (BV) was pipetted onto a smear pad (Hi-Q Environmental Products Company, part number FP1441-20), allowed to dry, and subjected to a 5-minute count. The average count over the 5 minutes was background corrected and compared to the standard curve in Figure 1 to determine the concentration of pertechnetate.

Figure 1. Calibration Curve using Ludlum Model 2929.

\section{cpm vs 99Tc in simulant}

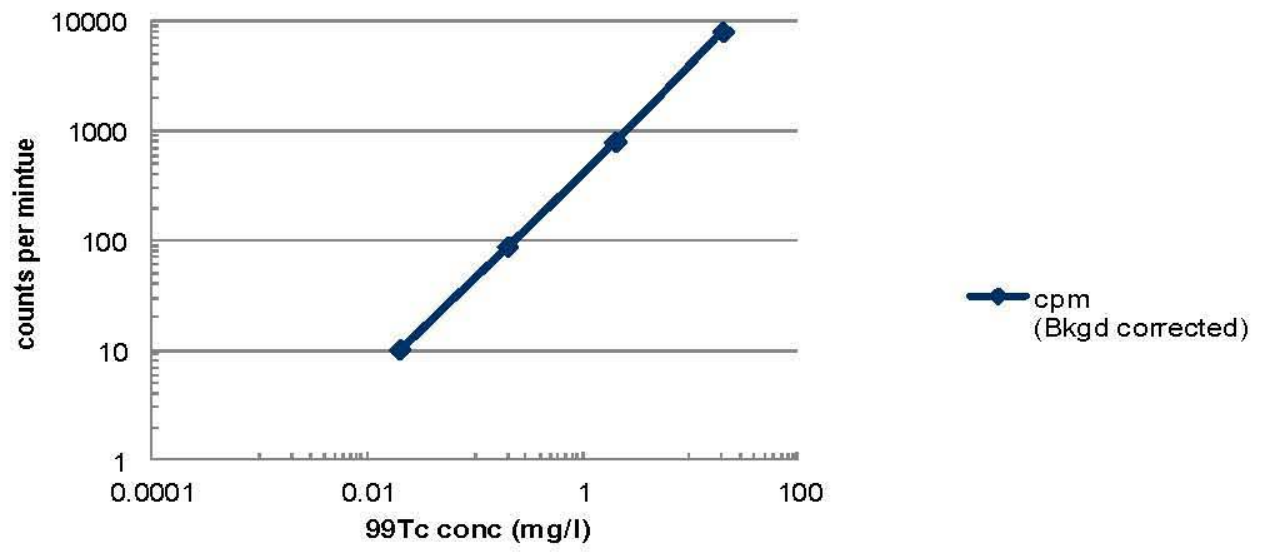

\footnotetext{
${ }^{2}$ PerkinElmer is a registered trademark of PerkinElmer, Inc., Wellesley, Massachusetts.
} 


\section{LAB-RPT-12-00001 Rev. 0}

\section{$2.3 \quad$ Sn(I)APATITE SYNTHESIS}

Sn(II)apatite was synthesized using a ChemGlass ${ }^{\circledR 3}$ 2-L reactor, as shown in Figure 2. One liter of DI water was added to the reactor and heated to boiling to eliminate as much carbon dioxide as possible. According to McConnell and Foreman (1966) "carbon dioxide substitution for phosphate will take place unless great care is exercised to exclude carbon dioxide from all reagents including the water" during the preparation of apatite. After several minutes of boiling, the heat was reduced to $37^{\circ} \mathrm{C}$ and high purity nitrogen gas was sparged into the water. Three milliters of hydrazine was added after the temperature reached $37^{\circ} \mathrm{C}$ for reducing conditions.

\section{Figure 2. Bench Set-up for Synthesis of $\operatorname{Sn}($ II) ap atite.}

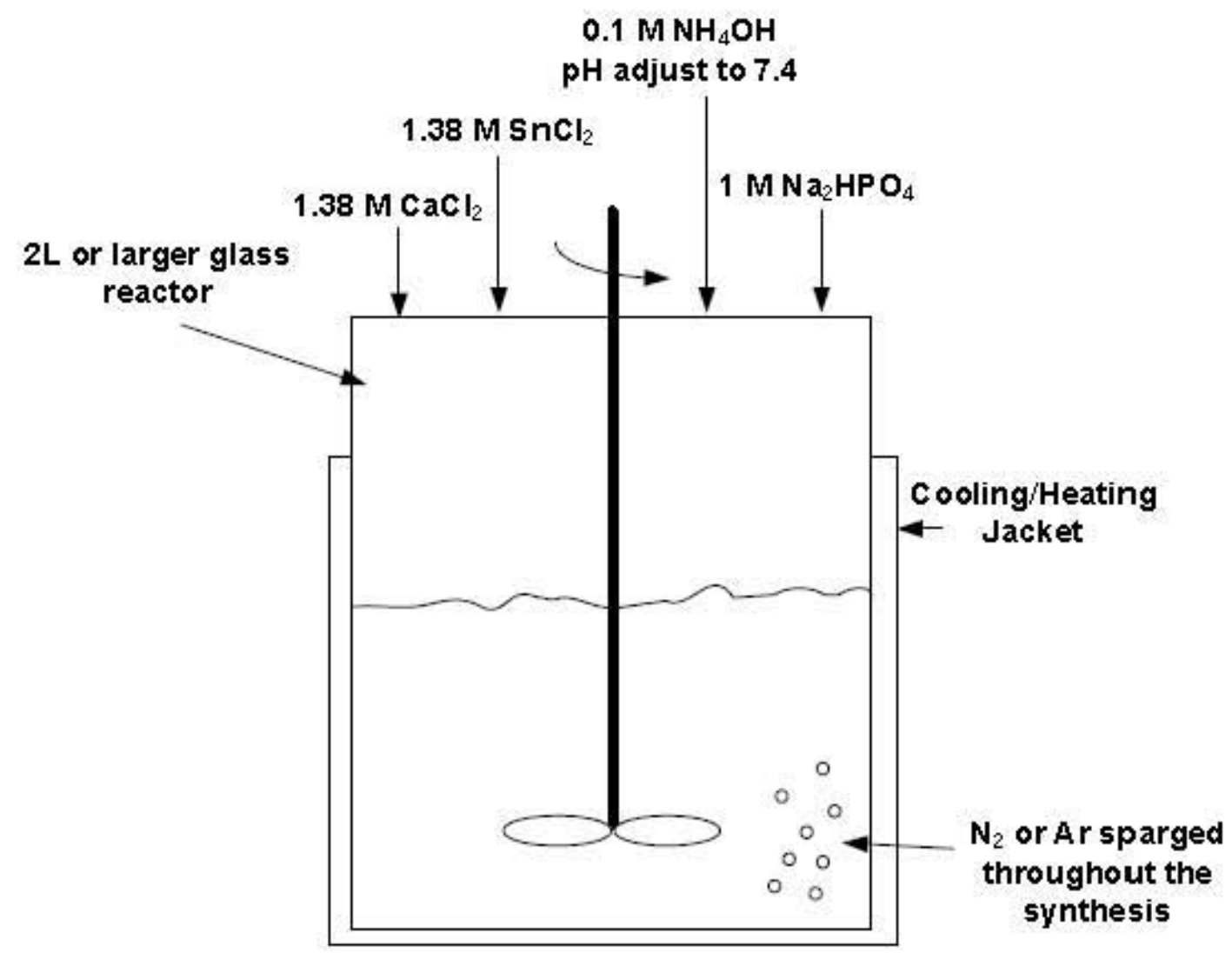

${ }^{3}$ ChemGlass is a registered trademark of ChemGlass, Inc, Vineland, New Jersey. 


\section{LAB-RPT-12-00001 Rev. 0}

The procedure to synthesize $\mathrm{Sn}(\mathrm{II})$ apatite is as follows:

Note: The Sn(II) must be kept from oxidizing during the synthesis. This is accomplished by keeping all oxygen out of the system and/or adding a reducing agent $(3 \mathrm{~mL}$ of hydrazine) to the $\mathrm{SnCl}_{2}$ reagent solution and the initial DI $\mathrm{H}_{2} \mathrm{O}$ in the reactor vessel.

1. Bring the water $(1 \mathrm{~L})$ in the reactor to a boil and cool to $37{ }^{\circ} \mathrm{C}$ while sparging with $\mathrm{N}_{2}$ or Ar gas. Add the reducing agent.

2. Prepare $250 \mathrm{~mL}$ of $1.0 \mathrm{M} \mathrm{Na}_{2} \mathrm{HPO}_{4}$ solution and adjust the $\mathrm{pH}$ to 7.4 with $\mathrm{NH}_{4} \mathrm{OH}$. Purge any air from the flask.

3. Prepare $250 \mathrm{~mL}$ of $1.38 \mathrm{M} \mathrm{CaCl}_{2}$ solution and adjust the $\mathrm{pH}$ to 7.4 with $\mathrm{NH}_{4} \mathrm{OH}$. Purge any air from the flask.

4. Prepare the $\mathrm{SnCl}_{2}$ solution by adding $1 \mathrm{~mL}$ of hydrazine to $250 \mathrm{~mL}$ of DI, degassed water, and then add the $\mathrm{SnCl}_{2}$ to make a $0.4 \mathrm{M}$ solution. Purge any air space in the vessel with $\mathrm{N}_{2}$ or $\mathrm{Ar}$ and seal the vessel. Do not adjust the $\mathrm{pH}$.

5. While maintaining the reactor at $37^{\circ} \mathrm{C}$, slowly add the reagents at the flowrate of approximately $1 \mathrm{~mL} / \mathrm{min}$., all the while vigorously stirring and bubbling $\mathrm{N}_{2}$ or Ar through the solution.

6. The $\mathrm{pH}$ of the solution must be maintained at approximately $7.4 \pm 0.2$. The entire first phase of the procedure takes about 6 hours to complete.

7. After all reagents have been added, keep stirring the mixture and bubbling in $\mathrm{N}_{2}$ or $\mathrm{Ar}$ overnight, maintaining the temperature at $37^{\circ} \mathrm{C}$ and the $\mathrm{pH}$ at 7.4 at all times. For a more crystalline material, let it set for additional time, 2-3 days to allow Ostwald ripening.

8. Filter the $\mathrm{Sn}(\mathrm{II})$ apatite using a Buchner funnel and $0.65 \mu \mathrm{m}$ filter paper. Repulp the $\mathrm{Sn}(\mathrm{II})$ apatite and filter it two more times. Place the product apatite into a Pyrex ${ }^{\circledR 4}$ vial and dry for $24 \mathrm{hrs}$ at $50^{\circ} \mathrm{C}$ under a constant flow blanket of dry, high purity nitrogen. (If the material is placed in an oven to dry, the $\mathrm{Sn}(\mathrm{II})$ will oxidize to $\mathrm{Sn}(\mathrm{IV})$.)

Upon completion of this procedure, the $\mathrm{Sn}$ (II)apatite formed large white aggregates as shown in Figure 3. In order to achieve more surface area for use in the contact experiments, the $\mathrm{Sn}$ (II)apatite was placed in liquid nitrogen to minimize oxidation of the tin and ground to a fine powder using a mortar and pestle.

\footnotetext{
${ }^{4}$ Pyrex is a registered trademark of Corning Glass Works Corporation, Corning, New York.
} 


\subsection{CHALLENGES TO Sn(II)APATITE}

Initially, the main interest in the $\operatorname{Sn}($ II) apatite was to reduce and sequester pertechnetate from a tank waste simulant of high $\mathrm{pH}$ and high ionic strength. However, the $\mathrm{Sn}$ (II)apatite may also have value in the reduction and sequestering of pertechnetate in other less aggressive media. To that end, the $\mathrm{Sn}$ (II)apatite was challenged across the $\mathrm{pH}$ range with varying molarities of sodium in the AN-105 simulant for the high $\mathrm{pH}$ range, as well as with DI water and nitric acid spiked with pertechnetate for the lower $\mathrm{pH}$ ranges.

\subsection{RESULTS AND DISCUSSION}

\subsection{Sn(II)APATITE}

Figure 3 shows the product derived from the synthesis description in Section 2.3.

Figure 3. Sn(II)apatite on a Scanning Electron Microscope Mount. (Mount is $1 \mathrm{~cm}$ diameter.)

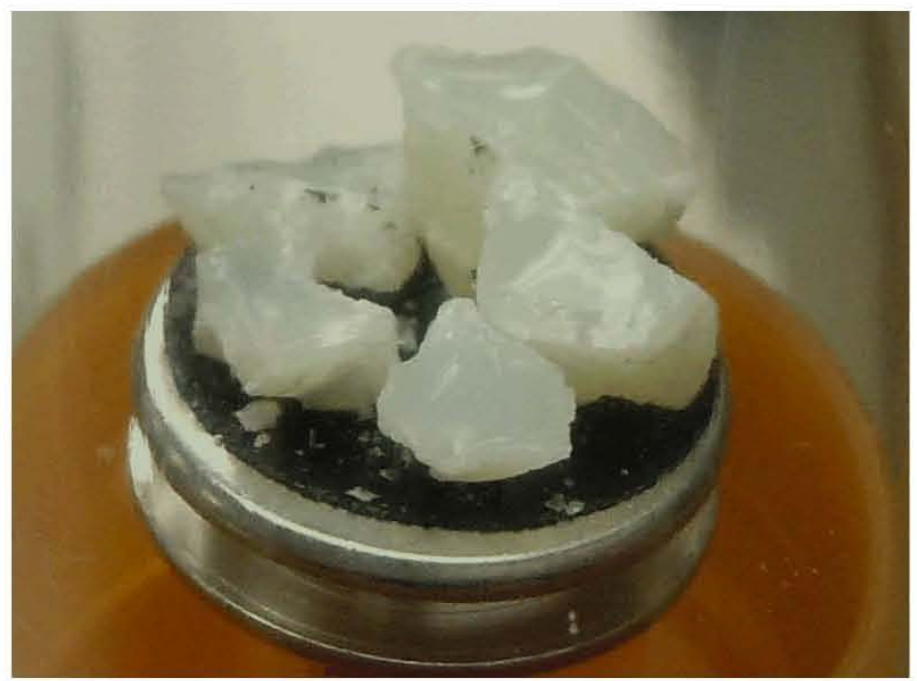


Figure 4 shows a secondary electron image with electron dispersive spectrom etry (EDS) spectrum indicating the relative intensities of the identified elements.

Figure 4. Secondary Electron Image with EDS of Sn(II)apatite.

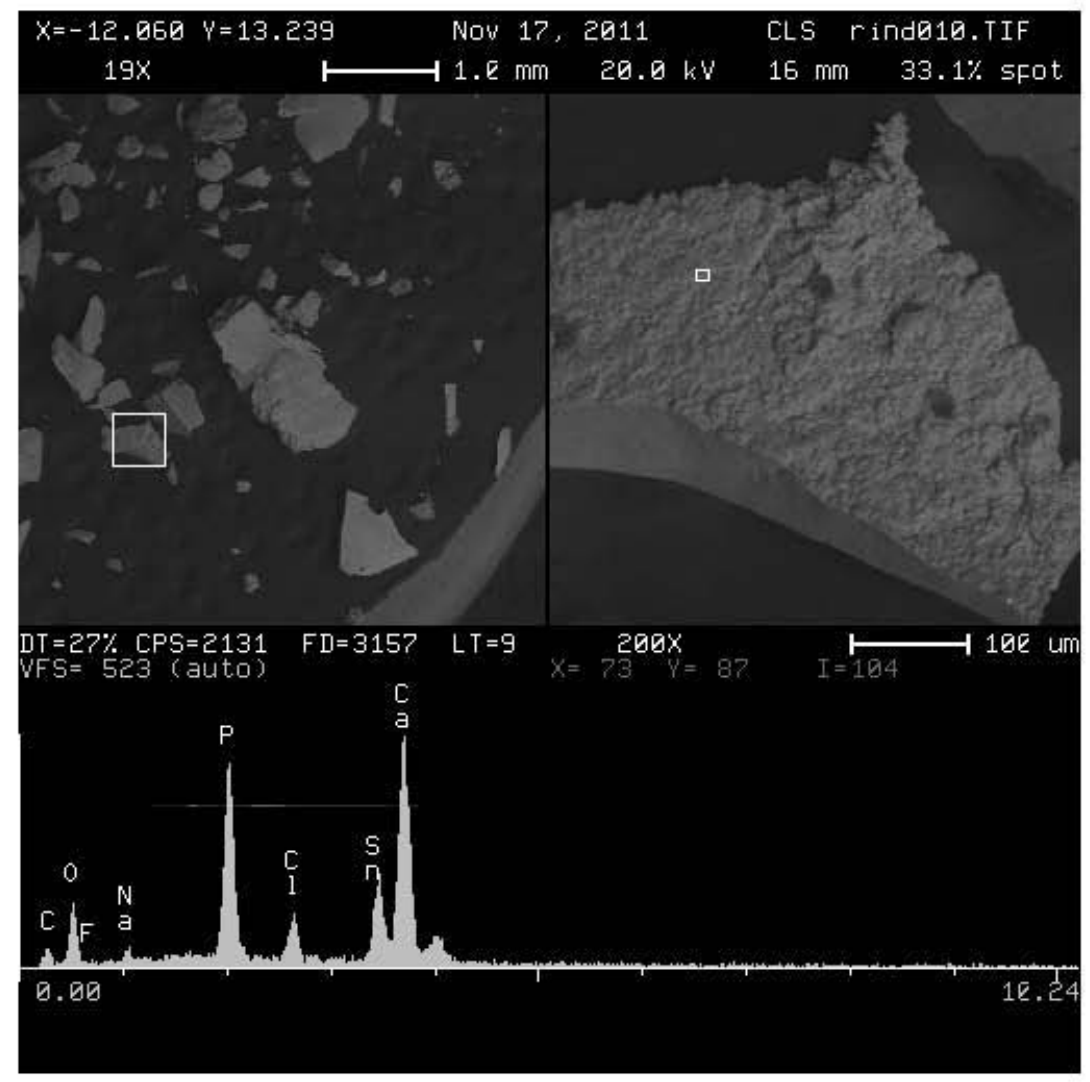

An X-ray diffraction (XRD) scan is presented in Figure 5. The XRD pattern indicates the presence of a poorly crystallized hydroxyapatite, but does not indicate the presence of either a crystalline $\mathrm{Sn}(\mathrm{II})$ or $\mathrm{Sn}(\mathrm{IV})$ compound. It is known that poorly crystallized apat ite has a higher solubility and is much more reactive than highly crystalline apatite. These results are consistent with the rapid reduction and immobilization of technet ium by this material. 
LAB-RPT-12-00001 Rev. 0

Figure 5. X-ray Diffraction Pattern of the Sn(II)apatite Formulation.

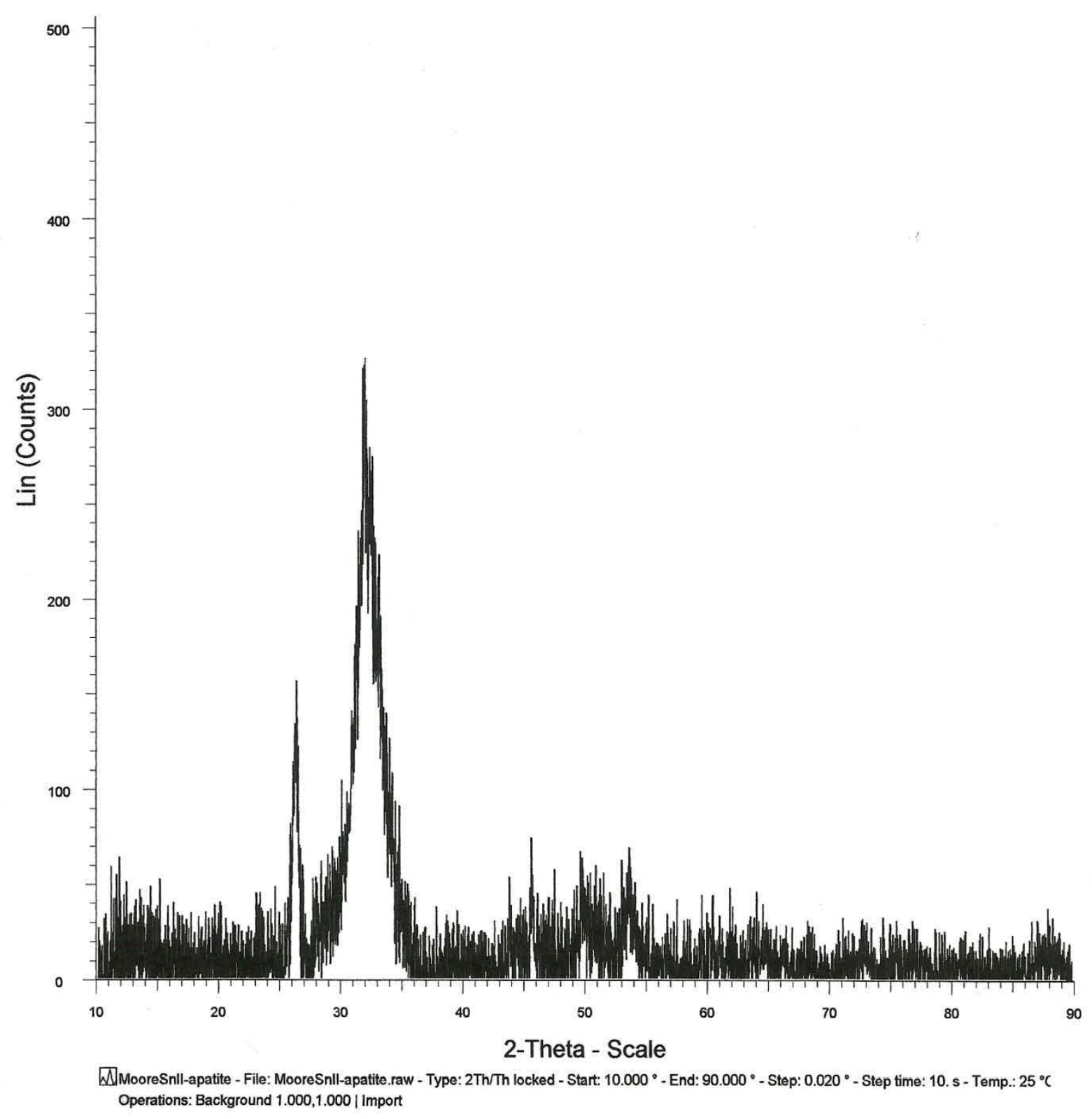

\subsection{DISTRIBUTION COEFFICIENTS}

The $\mathrm{Sn}$ (II)apatite was initially challenged with the AN-105 simulant. In order to determine the range of usability in the field, the $\mathrm{Sn}(\mathrm{II})$ apatite was challenged against a range of $\mathrm{pH}$ and sodium molarities. Included in the challenge was DI water (spiked with pertechnetate). Table 2 shows the results of the distribution coefficients $\left(\mathrm{K}_{\mathrm{d}}\right)$ as a function of $\mathrm{pH}$. The challenge media from 


\section{LAB-RPT-12-00001 Rev. 0}

AN-105 simulant was made from dilutions of the initial $10 \mathrm{M} \mathrm{Na}$ simulant. The dilutions were carried out using Milli-Q ${ }^{\circledR 5}$ water with no visible precipitate formed. The $\mathrm{pHs}$ reported in Table 3 are measured values, and Appendix A presents the data from which the distribution coefficients were derived.

The $\mathrm{K}_{\mathrm{d}}$ was determined using Equation 1 (Ion Exchange, Helfferich 1962):

$$
\mathrm{K}_{\mathrm{d}}=[\text { mass in the solid phase }] /[\text { mass in liquid phase }] * \mathrm{~V}_{\mathrm{s}} / \mathrm{m}_{\mathrm{e}}
$$

Where:

$$
\begin{aligned}
& \mathrm{K}_{\mathrm{d}} \quad=\text { distribution coefficient } \\
& \mathrm{V}_{\mathrm{s}}=\text { volume of the solution } \\
& \mathrm{m}_{\mathrm{e}}=\text { mass of the sorbent (dry weight) }
\end{aligned}
$$

\begin{tabular}{|c|c|c|c|}
\hline Challenge Media & $\begin{array}{c}\text { Initial Tc-99 } \\
\text { Concentration } \\
(\mathrm{mg} / \mathrm{L})\end{array}$ & $\begin{array}{c}\text { Distribution Coefficient, } \\
\mathrm{K}_{\mathrm{d}} \\
\mathrm{mL} / \mathrm{g}\end{array}$ & pH \\
\hline $10 \mathrm{MNa}$ & 15.2 & 36 & $>14$ \\
\hline $1.25 \mathrm{MNa}$ & 17.1 & 68 & 13.3 \\
\hline $0.125 \mathrm{MNa}$ & 17.1 & 703 & 12.5 \\
\hline $0.0125 \mathrm{MNa}$ & 17.1 & 65,669 & 11.4 \\
\hline $0.00125 \mathrm{MNa}$ & 17.1 & $170,900^{\mathrm{a}}$ & 10.2 \\
\hline $0.000125 \mathrm{MNa}$ & 17.1 & $170,900^{\mathrm{a}}$ & 8.5 \\
\hline DI Water (spiked) & 17.1 & $170,900^{\mathrm{a}}$ & 2.5 \\
\hline $0.05 \mathrm{M} \mathrm{HNO}_{3}$ & 17.1 & 6,059 & 1.3 \\
\hline $0.1 \mathrm{M} \mathrm{HNO}_{3}$ & 17.1 & 237 & 1 \\
\hline $1.0 \mathrm{M} \mathrm{HNO}_{3}$ & 17.1 & 18 & 0.1 \\
\hline
\end{tabular}

Table 3. Distribution Coefficients as a Function of Sodium Molarity and pH.

As indicated in the above table, the $\mathrm{Sn}$ (II)apatite imparts an impressive distribution coefficient against pertechnetate within a $\mathrm{pH}$ range of $1<\mathrm{pH}<12$. However, when compared to ion exchange sorbents such as Purolite ${ }^{6}$ A530E which achieves a distribution coefficient of $\sim 900$ in a $10 \mathrm{M}$ sodium AN-105 simulant (LAB-RPT-12-00002, Laboratory Report on the Removal of Pertechnetate from Tank 241-AN-105 Simulant using Purolite A530E), the Sn(II)apatite does not perform as well in the higher alkalinity ranges.

\subsection{NITRIC ACID LEACH TESTS}

In order to ascertain how well the $\mathrm{Sn}$ (II)apatite protected the $\mathrm{TcO}_{2}$ from re-oxidation to the more stable and water-soluble pertechnetate species, a series of nitric acid washes was carried out. A

${ }_{6}^{5}$ Milli-Q is a registered trademark of the Millipore Corporation, Billerica, Massachusetts.

${ }^{6}$ Purolite is a registered trademark of Brotech Corporation, Bala Cynwyd, Pennsylvania. 
mass of $200 \mathrm{mg}$ of $\mathrm{Sn}$ (II)apatite was loaded with $0.311 \mathrm{mg}$ of Tc-99. The Sn(II)apatite containing $\mathrm{TcO}_{2}$ was mixed with the molarities of nitric acid (as indicated in Table 3), gently shaken for 1 minute, and filtered using a syringe filter; the filtrate was then analyzed for technetium, using an ICP-MS. The process was repeated for a total of two washes. Table 4 presents the results of the test.

Table 4. Weight Percent Technetium Lost in Nitric Acid Washes.

\begin{tabular}{|l|c|c|}
\hline \multirow{2}{*}{ Solution } & \multicolumn{2}{|c|}{ Tc-99 Leached into Filtrate (wt\%) } \\
\cline { 2 - 3 } & First Wash & Second Wash \\
\hline $0.01 \mathrm{M} \mathrm{HNO}_{3}$ & Non Detect & Non Detect \\
\hline $0.05 \mathrm{M} \mathrm{HNO}_{3}$ & 0.52 & 0.33 \\
\hline $0.1 \mathrm{M} \mathrm{HNO}_{3}$ & 0.24 & 0.19 \\
\hline $1 \mathrm{M} \mathrm{HNO}_{3}$ & 0.31 & 50.0 (after a 72-hour soak) \\
\hline
\end{tabular}

As can be seen from the above table, the apatite-technetium complex is stable against a robust oxidation attack. Only after leaving the loaded $\mathrm{Sn}$ (II)apatite sample in contact with $1 \mathrm{M}$ nitric acid for 3 days was a considerable amount of Tc-99 (50 weight per cent) released. Due to budget and time constraints, the lower nitric acid molarities were not tested at longer times, and therefore a release rate cannot be determined. The test does indicate that Tc-99 is chemisorbed rather than physisorbed.

\subsection{WATER COLUMN LEACH TESTS}

The next test carried out was to ascertain whether or not the apatite-technetium complex would be subjected to releasing technetium if exposed to a more "environmentally friendly" oxidation. For the water leach test, $0.342 \mathrm{mg}$ of technetium was captured by $200 \mathrm{mg}$ of Sn(II)apatite, placed in a $200-\mathrm{mL}$ graduated cylinder, and continually sparged with air. The results are presented in Table 5.

Table 5. Water Leach Test.

\begin{tabular}{|c|c|c|}
\hline Exposure Time & $\begin{array}{c}\text { Dissolved Oxygen } \\
(\mathbf{m g} / \mathbf{L})\end{array}$ & $\begin{array}{c}\text { Technetium Concentration } \\
(\mathbf{m g} / \mathbf{L})^{\mathbf{a}}\end{array}$ \\
\hline 2 hours & 8.7 & $<0.01$ \\
\hline 24 hours & 8.6 & $<0.01$ \\
\hline 1 week & 8.6 & $<0.01$ \\
\hline 2 weeks & 8.4 & $<0.01$ \\
\hline 3 weeks & 8.6 & $<0.01$ \\
\hline 4 weeks & 8.4 & $<0.01$ \\
\hline 5 weeks & 8.4 & $<0.01$ \\
\hline 6 weeks & 8.6 & $<0.01$ \\
\hline
\end{tabular}

${ }^{a}$ Activity determined by Ludlum and recalculated to $\mathrm{mg} / \mathrm{L}$

The data from Table 5 indicates the sequestered technetium is protected from re-oxidation from the technetium dioxide to the pertechnetate species in an oxygenated water column. 


\subsection{PROPOSED SEQUESTRATION MECHANISM}

In order to gain insight into the reactions associated with the technetium retention by $\mathrm{Sn}$ (II)apatite, pertechnetate was reacted with $\mathrm{Sn}$ (II)apatite in DI water. After the reaction, the water was analyzed for phosphorous and calcium. The results indicate that there were $0.173 \mathrm{mmol}$ of technetium taken up by the apatite, while $0.177 \mathrm{mmol}$ of phosphorous and 0.308 mmol of calcium were released. The results are presented in Table 6.

Table 6. Analyses of De-ionized Water Medium.

\begin{tabular}{|c|c|c|c|c|c|c|c|}
\hline $\begin{array}{c}\text { Amount used } \\
\text { to Synthesize } \\
\text { An(II)apatite } \\
\text { M/L }\end{array}$ & $\begin{array}{l}\text { Analyte } \\
\text { in } \\
\text { Solution }\end{array}$ & 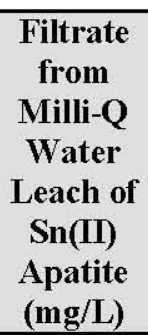 & $\begin{array}{c}\text { Milli-Q } \\
\text { Water } \\
\text { mg/L by } \\
\text { itself }\end{array}$ & $\begin{array}{c}\text { Tc-99 } \\
\text { Bearing } \\
\text { Solution }\end{array}$ & $\begin{array}{c}\text { Filtrate after } \\
\text { Reaction of } \\
\text { Sn(II)apatite } \\
\text { with } 17.1 \\
\text { mg/L Tc-99 } \\
\text { Solution } \\
\text { (mg/L) }\end{array}$ & $\begin{array}{c}\begin{array}{c}\text { Difference } \\
\text { of Filtrates } \\
(\mathrm{mg} / \mathrm{L})\end{array} \\
\end{array}$ & $\begin{array}{c}\begin{array}{c}\text { Difference } \\
\text { of Filtrates } \\
(\mathrm{mmol} / \mathrm{L})\end{array}\end{array}$ \\
\hline 1 & $\mathrm{P}$ & 0.216 & 0.042 & 0 & 5.754 & 5.496 & 0.177 \\
\hline 1.38 & $\mathrm{Ca}$ & 30.756 & 0.103 & 0 & 43.194 & 12.335 & 0.308 \\
\hline 1.38 & Sn & $\begin{array}{l}0.447 \\
\text { (ug/L) }\end{array}$ & $\mathrm{ND}$ & 0 & $\begin{array}{l}0.465 \\
\text { (ug/L) }\end{array}$ & $0.018(\mathrm{ug} / \mathrm{L})$ & $1.52 \mathrm{E}-7$ \\
\hline$\overline{\mathrm{NA}^{\mathrm{a}}}$ & Tc-99 & NA & $\overline{\mathrm{NA}}$ & 17.1 & $\overline{\mathrm{ND}}$ & 17.1 & 0.173 \\
\hline
\end{tabular}

The calcium may be in excess in the control due to substitution of tin for calcium (see McConnell and Foreman, 1966). The calcium that appeared in the Sn(II)apatite-loaded Tc-99 water analysis may well be a calcium phosphate compound, which cannot be ruled out and it is beyond the present scope to ascertain the exact composition of the leaving analytes.

The more probable explanation is that the technetium dioxide substituted for phosphate. Elliott et al., (2002), reported that the apatite lattice is very tolerant of substitutions, vacancies, and solid solutions; the phosphate can be replaced by arsenate $\left(\mathrm{AsO}_{4}{ }^{3-}\right)$, orthovanadate $\left(\mathrm{VO}_{4}{ }^{3-}\right)$, silicate $\left(\mathrm{SiO}_{4}{ }^{4-}\right)$, or carbonate $\left(\mathrm{CO}_{3}{ }^{2-}\right)$.

The protection of reduced technetium in the $\mathrm{Sn}$ (II)apatite complex from re-oxidation by nitric acid and less robust oxygenated water indicates that there is actual incorporation into the crystal structure rather than a mechanism such as surface physisorption.

In order to truly answer the question of what mechanism occurs to sequester technetium dioxide and protect from reoxidation would involve $a b$ inito quantum calculations involving van der Waals radii, electronegativity values (Pauling), and lattice forces, to name a few parameters. A possible place to begin would be the use of the Born-Oppenheimer Schrödinger equation. The Born-Oppenheimer Hamiltonian, giving total energy of the system, would allow calculations of the electron kinetic energy, nuclear attraction energy, electrical repulsion energy, and the nuclear repulsion energy. It is highly recommended that a mechanism be delineated to aid in the understanding of the protection that $\mathrm{Sn}$ (II)apatite will afford to the reoxidation of technetium dioxide to pertechnetate. 


\section{LAB-RPT-12-00001 Rev. 0}

\subsection{CONCLUSIONS}

From the results presented and discussed above, the $\mathrm{Sn}$ (II)apatite is not applicable to being used on direct Hanford tank waste at the high $\mathrm{pH}$ that it will encounter.

However, for diluted waste streams ( $\mathrm{pH}$ between 2 and 11), it appears to be a robust candidate for sequestering Tc-99 from a liquid stream and immobilizing it in a solid crystal form.

The indications are that the Sn(II)apatite will lend itself to sequestering and inhibiting the reoxidation to the mobile pertechnetate species, thus keeping the radionuclide out of the environment. The Sn(II)apatite would be efficacious in the reduction and sequestration of pertechnetate in the following scenarios, for example:

- water elution from pertechnetate resins such as SuperLig ${ }^{\circledR} 639$

- treatment of pertechnetate-containing waste streams from the Effluent Treatment Facility

- treatment of the off gas from the Waste Treatment Plant to capture technetium

- groundwater barrier to prevent pertechnetate mobility.

\subsection{REFERENCES}

Aarkrog, A., Q. Chen, H. Dahlgaard, S.P. Nielsen, A. Trapeznikov, and V. Pozolotina, 1997, "Evidence of ${ }^{99} \mathrm{Tc}$ in Ural River sediments," J. Environ. Radioactivity, Vol. 37, Issue 2, pp. 201-213.

ANSI/ANS-16.1-2003, Measurement of the Leachability of Solidified Low-Level Radioactive Wastes by a Short-term Test Procedure, American Nuclear Society, La Grange Park, Illinois.

Elliott, J. C., R. M. Wilson, and SEP Dowker, 2002, "Apatite Structures," Advances in X-ray Analysis, Vol. 45, pp. 172-181, London, UK.

Helfferich, F., 1962, Ion Exchange, McGraw-Hill Book Co., New York.

Hu, Q. H., T. P. Rose, M. Zavarin, D. K. Smith, J. E. Moran, and P. H. Zhao, 2008, "Assessing field-scale migration of radionuclides at the Nevada Test Site: 'mobile' species," J. Environ. Radioactivity, Vol. 99, Issue 10, pp. 1617-1630.

IAEA, 2010, Handbook of Parameter Values for the Prediction of Radionuclide Transfer in Terrestrial and Freshwater Environments, Technical Reports Series No. 472, Vienna, Austria. 


\section{LAB-RPT-12-00001 Rev. 0}

LAB-PLN-11-00010, 2011, Evaluation of Technetium Ion Exchange Material against Hanford Double Shell Tank Supernate Simulate with Pertechnetate, R0, Washington River Protection Solutions LLC, Richland, Washington.

LAB-RPT-12-00002, 2012, Laboratory Report on the Removal of Pertechnetate from Tank 241AN-105 Simulant using Purolite A530E, R0, Washington River Protection Solutions LLC, Richland, Washington.

McConnell, D. and D. W. Foreman, 1966, "The properties and structure of $\mathrm{Ca}_{10}\left(\mathrm{PO}_{4}\right)_{6}(\mathrm{OH})_{2}$; its relation to tin (II) apatite," The Canadian Mineralogist, Vol. 8, Issue 4, pp. 431-436.

Radiological and Chemical Fact Sheets to Support Health Risk Analyses for Contaminated Areas, "Technetium," 2005, Argonne National Laboratory, Argonne, Illinois.

RPP-RPT-39195, 2009, Assessment of Technetium Leachability in Cement-Stabilized Basin 43 Groundwater Brine, R1, Washington River Protection Solutions LLC, Richland, Washington.

Smith, V., M. Fegan, D. Pollard, S. Long, E. Hayden, and T. P. Ryan, 2001, "Technetium-99 in the Irish marine environment," J. Environ. Radioactivity, Vol. 56, Issue 3, pp. 269-284.

UCRL-JRNL-212334, 2005, Current Status of the Thermodynamic Data for Technetium and its Compounds and Aqueous Species, Lawrence Livermore National Laboratory, Livermore, California.

WSRC-TR-2000-00338, 2001, Hanford Waste Simulants Created to Support the Research and Development on the River Protection Project - Waste Treatment Plant, Westinghouse Savannah River Company, Aiken, South Carolina. 
LAB-RPT-12-00001 Rev. 0

APPENDIX A

Technetium Distribution Coefficient Data 
LAB-RPT-12-00001 Rev. 0

Appendix A

\begin{tabular}{|c|c|c|c|c|c|c|c|c|c|}
\hline \multicolumn{10}{|c|}{ Technetium Distribution Coefficient Data } \\
\hline & \multirow{2}{*}{$\begin{array}{c}\text { Tc-99 Conc } \\
\text { mg/L }\end{array}$} & \multirow{2}{*}{$\begin{array}{l}\text { Tc-99 Initial } \\
\text { mg }\end{array}$} & \multirow{2}{*}{$\begin{array}{c}\text { Tc Final } \\
\mathrm{mg} / \mathrm{L}\end{array}$} & \multirow{2}{*}{$\begin{array}{c}\text { Tc Final } \\
\text { mg }\end{array}$} & \multirow{2}{*}{$\begin{array}{l}\text { Tc Conc in } \\
\text { Solid Phase }\end{array}$} & \multirow{2}{*}{$\begin{array}{l}\text { Sn(II)apatite } \\
\text { Mass, g,(dry) }\end{array}$} & \multirow{2}{*}{$\begin{array}{c}\text { Volume } \\
\mathrm{mL}\end{array}$} & \multirow{2}{*}{$\begin{array}{c}\text { Volume } \\
\text { L }\end{array}$} & $\mathrm{Kd}$ \\
\hline Media $^{a}$ & & & & & & & & & $\mathrm{~mL} / \mathrm{g}$ \\
\hline $10 \mathrm{M} \mathrm{Na}$ & 15.2 & 0.304 & 11.2 & 0.224 & 0.08 & 0.2 & 20 & 0.02 & 36 \\
\hline $1.25 \mathrm{MNa}$ & 17.1 & 0.342 & 10.2 & 0.204 & 0.138 & 0.2 & 20 & 0.02 & 68 \\
\hline $0.125 \mathrm{MNa}$ & 17.1 & 0.342 & 2.13 & 0.0426 & 0.2994 & 0.2 & 20 & 0.02 & 703 \\
\hline $0.0125 \mathrm{MNa}$ & 17.1 & 0.342 & 0.026 & 0.00052 & 0.34148 & 0.2 & 20 & 0.02 & 65669 \\
\hline $0.00125 \mathrm{M} \mathrm{Na}$ & 17.1 & 0.342 & 0.01 & 0.0002 & 0.3418 & 0.2 & 20 & 0.02 & 170900 \\
\hline $0.000125 \mathrm{M} \mathrm{Na}$ & 17.1 & 0.342 & 0.01 & 0.0002 & 0.3418 & 0.2 & 20 & 0.02 & 170900 \\
\hline DI water spiked & 17.1 & 0.342 & 0.01 & 0.0002 & 0.3418 & 0.2 & 20 & 0.02 & 170900 \\
\hline $0.05 \mathrm{M} \mathrm{HNO} 3$ & 17.1 & 0.342 & 0.278 & 0.0056 & 0.3364 & 0.2 & 20 & 0.02 & 6059 \\
\hline $0.1 \mathrm{M} \mathrm{HNO} 3$ & 17.1 & 0.342 & 5.070 & 0.1014 & 0.2406 & 0.2 & 20 & 0.02 & 237 \\
\hline $1.0 \mathrm{MHNO} 3$ & 17.1 & 0.342 & 14.541 & 0.2908 & 0.0512 & 0.2 & 20 & 0.02 & 18 \\
\hline
\end{tabular}




\section{Electronically Approved by:}

UserName: Duncan, James (h0079048)

Title: APD Chemist

Date: Wednesday, 13 June 2012, 04:05 PM Pacific Time

Meaning: Approved by the author or delegate

UserName: Russell, Rose (h5476814)

Title:

Date: Thursday, 14 June 2012, 09:27 AM Pacific Time

Meaning: Additional approval obtained

UserName: Russell, Rose (h5476814)

Title:

Date: Thursday, 14 June 2012, 09:39 AM Pacific Time

Meaning: Approved by the customer or delegate

UserName: Seidel, Cary (h0009079)

Title: APD Manager

Date: Monday, 18 June 2012, 08:53 AM Pacific Time

Meaning: Approved by the Group Manager or delegate 